\begin{abstract}
The global incidence of skin cancer and actinic keratosis (AK) has increased dramatically in recent years. Although many tumours are treated with surgery or radiotherapy topical therapy has a place in the management of certain superficial skin neoplasms and AK. This review considers skin physiology, non-melanoma skin cancer (NMSC), the relationship between AK and skin cancer and drugs administered topically for these conditions. The dermal preparations for management of NMSC and AK are discussed in detail. Notably few studies have examined drug disposition in cancerous skin or in AK. Finally, recent novel approaches for targeting of drugs to skin neoplasms and AK are discussed.
\end{abstract}

Key words: Skin, cancer, actinic keratosis, melanoma, topical, formulation 


\section{Topical therapies for skin cancer and actinic keratosis}

Tasnuva Haque ${ }^{1}$, Khondaker M. Rahman ${ }^{2}$, David E. Thurston ${ }^{2}$, Jonathan Hadgraft ${ }^{1}$, Majella E. Lane $^{1 *}$

${ }^{1}$ Department of Pharmaceutics, UCL School of Pharmacy, 29-39 Brunswick Square, London, WC1N 1AX

${ }^{2}$ Institute of Pharmaceutical Science, King's College London, Britannia House, 7 Trinity Street, London SE1 1DB, United Kingdom

*Corresponding author

Email: majella.lane@btinternet.com

Tel: +44 2077535821

Fax: +44 8701659275 


\begin{abstract}
The global incidence of skin cancer and actinic keratosis (AK) has increased dramatically in recent years. Although many tumours are treated with surgery or radiotherapy topical therapy has a place in the management of certain superficial skin neoplasms and AK. This review considers skin physiology, non-melanoma skin cancer (NMSC), the relationship between $\mathrm{AK}$ and skin cancer and drugs administered topically for these conditions. The dermal preparations for management of NMSC and AK are discussed in detail. Notably few studies have examined drug disposition in cancerous skin or in AK. Finally, recent novel approaches for targeting of drugs to skin neoplasms and AK are discussed.
\end{abstract}

Key words: Skin, cancer, actinic keratosis, melanoma, topical, formulation 


\section{Introduction}

Skin cancer is the most common cancer in Caucasian populations (Byrd-Miles et al., 2007). Damage of skin cell deoxyribonucleic acid (DNA) by ultraviolet (UV) radiation followed by failure of DNA repair mechanisms is the primary cause of these neoplasms. In the early stages, skin cancers develop in the outer layers of the skin. If not treated, they may grow deeper into the skin with development of metastases (secondary malignant growths distant from the primary origin). An actinic keratosis (AK) or solar keratosis is a scaly or crusty growth on the skin indicative of sustained damage by the sun. AK may progress to invasive neoplasms and have been interpreted as the earliest sign of skin cancer (Ibrahim and Brown, 2009). Early diagnosis is critical for the effective prognosis and treatment of patients with skin cancer. However, anticancer drugs which are administered orally or by the intravenous route are associated with serious side effects especially when given systemically. Topical dosage forms deliver most of the drug locally with fewer side effects compared with other routes of administration.

To date, a very limited number of molecules has been administered topically to skin cancer lesions or AK. This article provides a brief overview of skin physiology, describes the location and classes of skin cancers amenable to topical therapy and outlines the AK - skin cancer continuum. Surgery and chemotherapy are the definitive treatments for melanoma; therefore this type of cancer is only briefly reviewed here (Maverakis et al., 2014). Topical formulations are examined and, where available, skin penetration properties of the various drugs are detailed. New strategies for targeted drug delivery to skin cancers and AK are considered with an emphasis on studies conducted in vitro with porcine or human tissue, or in patients.

\section{Skin structure and physiology}

The various skin layers, appendages and cell subtypes are presented in this section as a prelude to discussion of the skin cancers most commonly reported, their causalities and location in the skin, which is detailed in the following section.

\subsection{Epidermis}


The skin acts as an interface between the internal organs and the environment. It is the largest organ of the human body and accounts for $10 \%$ of anatomic weight. Structurally, the skin is a multi-lamellar organ and it is involved in several physiological functions. The three layers of the skin are the epidermis, dermis and subcutaneous tissue. The outermost lamina of the epidermis, the stratum corneum (SC) represents the major barrier. This unique membrane prevents excessive water loss and is the major route for the percutaneous absorption of exogenous material as reviewed in detail by Menon et al. (2012), and Baroni et al. (2012).

The epidermis is a multi-layered structure whose thickness varies from $0.8 \mathrm{~mm}$ (on the palms and soles) to $0.06 \mathrm{~mm}$ (on the eyelids). Histologically, the epidermis is further sub-divided into four different layers of cells (Figure 1). The cells (keratinocytes) that are present at the dermalepidermal junction form the stratum basale (or stratum germinativum). These cells contain nuclei, are columnar in shape and are anchored to the dermis via collagen fibres (Wertz and Downing, 1989). This layer also contains other cells, namely melanocytes, Langerhans cells and Merkel cells (Benson, 2012). Two billion melanocytes are distributed throughout the body with approximately 1500 melanocytes per square millimetre in skin but this may vary with anatomic site (Halaban et al. 2003). Melanocytes are triangular in shape and consist of a central cell body with a number of branches or dendrites (Figure 2).

Two melanin pigments are synthesised in the melanocytes: eumelanin, a dark brownblack insoluble polymer, and phaeomelanin, a light red-yellow sulphur containing soluble polymer (Ito and Wakamatsu, 2003). Melanin pigments are produced from tyrosine by an enzyme called tyrosinase through a series of oxidative steps and are stored in melanosomes which are specialised organelles present in melanocytes (Raposo and Marks, 2002). Melanosomes migrate to the neighbouring keratinocytes of the basal layer via the dendrites of the melanocytes (Figure 2). Along with keratinocytes, melanosomes also migrate towards the SC and finally disintegrate or eventually are shed from the surface of SC. Melanin protects the skin from UV-induced DNA-damage by directly absorbing UV photons and free radicals produced from the interaction of UV photons with cellular lipids (Park et al., 2009).

Above the stratum basale 2 to 6 rows of cell layers form the stratum spinosum (prickle cell layer or squamous cell layer). As keratinocytes migrate upwards from the stratum basale, their shapes change from columnar to polygonal and their nuclei decrease in size. The stratum granulosum overlays the spinosum cell layer and consists of 1 to 3 layers of cells. In this layer 
keratohyalin granules and membrane-coating granules are present and the latter are the precursors to the intercellular lipid lamellae of the SC. A separate layer, the stratum lucidum is present in the palm of the hand and sole of the foot. The cells of this layer are flat and compact and progress to become the anucleate and cornified dead cells of the SC (Benson, 2012).

The SC is predominantly composed of keratin $(70-80 \%)$ and lipid and consists of 10 to 15 layers of flattened, keratinised dead cells (corneocytes). Most of the lipid content of the SC is present between the corneocytes (Elias et al., 1981). The thickness of this layer is only 10 to $20 \mu \mathrm{m}$ when dry and it has been likened to a brick wall where the corneocytes are the 'bricks' present in the 'mortar' which represents the intercellular lipid matrix (Michaels et al., 1975). Desmosomes link corneocytes together, and a filamentous network of keratin is present in the cells which are surrounded by a protein-lipid rigid envelope (Figure 1). This envelope is highly resistant to external chemical assault and regulates the hydration between the intra- and extra-cellular environments of the corneocytes (Elias, 1988). The multiple lipid lamellae which occupy the intercellular space consist of ceramides $(41 \%)$, cholesterol $(27 \%)$, cholesterol esters $(10 \%)$, cholesterol sulphate (2\%) and free fatty acids (9\%). Water is also present in the SC, mainly associated with keratin with smaller amounts in the polar head groups of intercellular spaces (Suhonen et al., 1999). Proteolytic and lipolytic enzymes are also present in the SC that perform a range of biochemical activities, such as lipid processing and desmosome breakdown (Menon et al., 2012). It is the unique composition and ultrastructure of the SC which is responsible for its excellent barrier properties (Potts and Francoeur, 1991).

\subsection{Dermis}

The dermis or corium is about 20 to 30 times thicker ( 3 to $5 \mathrm{~mm}$ ) than the epidermis and consists of collagen fibrils and elastic connective tissues (Katz and Poulsen, 1971). Collagen is responsible for the strength of the skin and holding skin tissue together. Elastic connective tissue immersed in a semi-gel matrix of mucopolysaccharide provides flexibility. Cells present in the dermis include fibroblasts, mast cells, macrophages, lymphocytes and melanocytes. Blood vessels, nerves and skin appendages (sweat and sebaceous glands) are also present in this layer. Structurally, this layer does not offer the same resistance to drug penetration as the SC, however, reduced permeation of lipophilic drugs may be observed in this layer (Benson, 2012). Because of the rich 
blood supply in the dermis, this layer regulates temperature and pressure, supplies nutrition and is involved in waste regulation of the skin (Katz and Poulsen, 1971). Various receptors such as thermoreceptors, nociceptors, and some mechanoreceptors are also present in this tissue. The mechanoreceptors consist of Meissner's corpuscles and Pacinian corpuscles which recognise touch and pressure, respectively (McGrath and Pope, 2008).

\subsection{Subcutaneous tissue (hypodermis)}

The subcutaneous tissue is a specialised layer of fat cells interconnected by collagen and elastin fibres. This layer produces and stores large quantities of fat. It also acts as a heat insulator, protects the body from mechanical shock and stores large quantities of calories (Wood and Bladon, 1985)

\subsection{Skin appendages}

There are several appendages present in the dermis and epidermis of human skin, such as eccrine and apocrine sweat glands, sebaceous glands, hair follicles and nails. The eccrine sweat glands produce 99 to $99.5 \%$ water containing some electrolytes, with a $\mathrm{pH}$ of $\sim 5$. The glands primarily control the heat of the body. Apocrine sweat glands are distributed in the axillae, anogenital region and in the nipple area of the breast. The glands secrete milky or oily fluids. Sebaceous glands are mainly distributed on the face, forehead, anogenital surface, and chest and on the back of the body $\left(400-900\right.$ glands $\left./ \mathrm{cm}^{2}\right)$. The glands secrete sebum which mainly protects and lubricates the skin. Hair follicles are present throughout the body except on the palms, soles and in some parts of the lips and sex organs (Katz and Poulsen, 1971). Hair and nails contain hard keratin with the latter being formed of protective plates of protein. The cells of the nail plate develop in the nail matrix and the nail plate grows at a rate of $0.1 \mathrm{~mm} /$ day (Walters et al., 2012).

\section{Skin cancers and AK}

Skin cancer is broadly classified into two types based on its origin: non-melanoma skin cancer (NMSC) and melanoma. General risk factors for development of skin cancer include (i) skin phototype (i.e., how skin responds to ultraviolet [UV] radiation, also known as Fitzpatrick skin type), (ii) excessive exposure to UV radiation, and (iii) immunosuppression (Murphy, 2009). AK is 
recognised to exist in a continuum with NMSC, with $10 \%$ of $\mathrm{AK}$ lesions becoming cancerous if untreated (Fuchs and Marmur, 2007).

\subsection{Non-melanoma skin cancer (NMSC)}

Basal cell carcinoma (BCC) and squamous cell carcinoma (SCC) are classified as NMSCs. BCC and SCC develop in the basal and squamous (spinosum) layers of the epidermis, respectively (Wood and Bladon, 1985). BCC mainly occurs on the face and the back of the hands and most SCCs occur on the head and the neck. BCC grows slowly and spreads locally with little or no metastasis, however, SCC may progress to invasive SCC and there is a 2-6\% risk of metastasis (Jerant et al., 2000; Motley et al., 2002).

UV radiation is the primary cause of NMSC. The three regions of the UV spectrum are as follows: UV-A (320-400 nm), UV-B (280-320 nm) and UV-C (100-280 nm). However, UV-C is largely attenuated or absorbed by atmospheric gases. UV-B is the most carcinogenic radiation and induces a tan in the skin but causes burning first. Long term exposure to UV-B results in photoaging and cancer. UV-A is less harmful to human skin compared with UV-B (Maddodi and Setaluri, 2008; Madan, 2009). Exposure to UV radiation produces specific mutations in keratinocytes which leads to NMSC. Cellular DNA absorbs UV-B photons and generates a number of photoproducts. UV-A indirectly damages DNA by producing reactive oxygen species. If the DNA damage is not repaired, this causes specific DNA mutations. Mutations arise primarily by substitution of a single cytosine $(\mathrm{C})$ for a thymine $(\mathrm{T})$ base and, to a lesser extent, by substitution of a double base CC for TT at pyrimidine sites (Ratner et al., 2001). Protection against DNA damage or mutation from UV radiation requires DNA repair mechanisms and the production of melanin. In human cells, DNA photoproducts are mainly eliminated by a nucleotide excision repair (NER) mechanism. With increasing age, the DNA repair mechanism is decreased and the incidence of NMSC is higher in older patients (Bath-Hextall et al., 2007). In addition, in some genetic disorders such as in xeroderma pigmentosum, because of the defects in the NER gene, the DNA photoproducts cannot be removed. In such genetic defects the risk of developing NMSC is high. Melanin produced from melanocytes migrates into the surrounding keratinocytes in the basal layer of the epidermis and normally provides protection against UV radiation. However, melanin cannot prevent DNA damage in the superficial layers as it is shed from the SC along with keratinocytes. 
BCCs derive from the stratum basale, and may present as nodules or strands of cells (basaloids) which grow parallel to the epidermis. Nodular BCC is associated with well-defined "pearly" nodules and cell strands in the dermis. Superficial BCC presents as one or more erythematous lesions which are usually dry or scaly. Morpheaform or sclerosing BCC appears as thin strands of cells embedded in supporting tissue. Fibroepithelioma of Pinkus is a rare type of BCC found on the lower trunk or natal cleft; this presents as elongated strands of basaloids connected to overlying epidermis (McCormack et al., 1997; Goldenberg, 2010).

SCCs present with many distinct subtypes and diverse presentations. The carcinoma itself consists of atypical keratinocytes which may be present in all layers of the epidermis. Cells may present with faulty cornification, pale or vacuolated cytoplasm and nuclei may be present in cells of the stratum corneum (parakeratosis). The atypical keratinocytes do not penetrate into the dermis. Invasive SCC tumours originate in the epidermis, infiltrate the dermis and present as nests, sheets and strands of atypical keratinocytes. Dyskeratosis (premature keratinisation in cells not in the outer layers) as well as parakeratosis may be present variably in the tumour. These neoplasms may be further sub-classified depending on the extent of differentiation or keratinisation. With increasing depth of penetration of the tumour the risk of metastatic spread increases significantly. The histological patterns of the various SCCs and BCCs are illustrated and described in greater detail by Goldenberg and colleagues (Goldenberg, 2010). Keratoacanthoma is a neoplasm that originates from the hair follicles and is generally treated as a SCC (Schwartz, 2004).

\subsection{Melanoma}

Melanoma is a tumour which arises from the melanocytes (Wood and Bladon, 1985). It is the most lethal type of skin cancer and, unlike NMSC, is more common in younger and middleaged patients (Jerant et al., 2000; Ries et al, 2000). Besides skin, melanoma can develop in the eyes and the mucous membranes of the vagina, anus, sinus and oropharynx but occurrence in these sites consists of only 5\% of total melanomas (Kudchadkar and Weber, 2011). Cutaneous melanomas are classified as superficial spreading, lentigo maligna, nodular and acral lentiginous. It is not always possible to classify malignant melanomas (MMs) because of their varying presentations (Markovic et al., 2007). 
The main risk factor for melanoma is UV-B radiation, especially intermittent intense UV exposure. Individuals who burn but sometimes tan (Skin phototypes I and II) with light-hair are at greatest risk of melanoma (Bataille, 2013). There is a clear genetic association in a number of melanoma cases (Meyer and Zone, 1994). Mutations in the cyclin-dependent kinase inhibitor 2A (CDKN2A) and cyclin-dependent kinase 4 (CDK4) genes have been observed in families with inherited melanoma. Other genes have also been linked to a predisposition to melanoma (Aoude et al., 2015). Mutations in the B Rapidly Accelerating Fibrosarcoma (BRAF) gene are associated with 40-50\% of melanoma cases (Lee et al., 2011a). This gene encodes for the BRAF protein which plays an important role in regulating pathways involved in cell signalling, production and secretion. Mutations in the Neuroblastoma Rat Sarcoma (NRAS) gene have been found in 15-20\% of metastatic melanoma patients; this mutation achieves similar downstream effects as the BRAF mutation (Curtin et al., 2005; Lovly et al., 2012).

All primary MMs begin as a proliferation of melanocytes at the dermo-epidermal junction. MM becomes invasive as atypical melanocytes move into the dermis either individually or as aggregates. Some subtypes present with atypical melanocytes confined to the epidermis. Superficial spreading MM presents with atypical melanocytes at all levels of the epidermis with significant upward invasion of the epidermis. In the dermis atypical melanocytes may be present as individual cells or nests; melanocytes show failure of maturation with descent into the dermis. Melanoma progress has been classified as follows: Stage I and II are localised tumours which are restricted to the skin; Stage III is characterised by the involvement of lymph nodes and /or metastases and in Stage IV melanoma the metastases have spread to other organs or distant lymph nodes (Balch et al., 2009).

\subsection{Actinic keratosis (AK)}

AK also known as solar keratosis has been described as the earlier stage of SCC in situ (McGuire et al., 2000). AK is an important marker of increased risk for invasive SCC; both AK and SCC share genetic tumour markers and the same p53 gene (tumour suppressor gene) mutations (Cockerell, 2000). AK develops into SCC in several steps as shown in Figure 3. AK begins with DNA damage and mutations induced by UV radiation. The SCC development process starts with the development of a 'hot spot' or aggregation of small, microscopic transformed cells. Over time, 
the aggregates form keratinocytes and show features of atypia and pleomorphism. Depending on the patient's immune response, the lesions may remain unchanged or grow and extend into the dermis. Once the tumour cells are present in the dermis, it is termed SCC and subsequently tumour cells may become metastatic (Cockerell, 2000). AK lesions may present as dry, scaly patches appearing as pink, red or brown in colour and varying in size. Yellowing and thickening of the dermis (solar elastosis) is almost always present, and there may also be infiltration of lymphocytes and plasma cells (Röwert-Huber et al., 2007). Hypertrophic keratoses are a subtype of AK and present as thick and scaly plaques; they may also present with conical growths or "horns".

AK has been classified into three types based on the extent of atypical keratinocytes in the epidermis (Röwert-Huber et al., 2007). Grade 1: Atypical keratinocytes are found above and in the stratum basale layer, and may occupy the lower one third of the epidermis; irregularities are present in nuclei. Grade 2: Atypical keratinocytes are present in the lower two-thirds of the epidermis alternating with zones of normal epidermis; buds of keratinocytes may be found in the upper dermis. Grade 3: Atypical keratinocytes are present in more than two thirds of the epidermis including the epitheliae of hair follicles; keratinocyte buds may be present in the dermis.

\subsection{Kaposi's sarcoma}

Kaposi's sarcoma (KS) is a systemic disease caused by human herpes virus 8 (HHV 8). The condition presents with skin lesions, and there may or not be visceral involvement. There are four clinical subtypes: classic, endemic, immunosuppression-associated and AIDS-related. KS skin lesions vary in colour, are raised and generally appear on the lower limbs, genitalia, back, face and mouth. Histologically, the tumour evolves from patch and plaque stages to become nodular (Ackerman, 1985).

\section{Treatment of skin cancer and AK}

Local treatment of NMSC is determined based on the type, size, location of the lesion and patient age. Radiotherapy and surgery are the main treatment strategies. Lymph node dissection is also considered for SCCs as these tend to be more aggressive and have a higher tendency to 
develop metastasis (McGuire et al., 2009). Oral chemotherapy with retinoids and cisplatin, photodynamic therapy, topical chemotherapy with retinoids, flurouracil (FU), diclofenac sodium and imiquimod, and laser surgery are also used occasionally (Telfer et al., 2008; Kudchadkar and Weber, 2011). Table 1 summarises the drugs currently used for topical therapy which are discussed in more detail in later sections.

Depending on the stage of the cancer, melanoma may be treated by surgery, immunotherapy, targeted therapy, chemotherapy and radiotherapy. Surgery is the treatment option for primary melanoma. To boost the patient's immune response, an immunomodulator may be used, such as ipilimumab, cytokines (interferon-alpha, interleukin-II) or the Bacillus Calmette-Guérin (BCG) vaccine. Imiquimod cream may be used to stimulate the local immune response in early stage melanoma patients. Vemurafenib and dabrafenib, given orally, are BRAF kinase inhibitors and are used for late stage or advanced melanoma. Trametinib and selumetenib, also given orally, block a number of protein kinases of the signalling pathways activated in melanoma. Given systemically, dacarbazine and temozolomide (DNA methylating agents), cisplatin, carboplatin and carmustine (DNA cross-linking agents), and docetaxel, paclitaxel and vinblastine (tubulin inhibitors) are used as stand-alone chemotherapeutic agents for melanoma (Kudchadkar and Weber, 2011; Homet and Ribas, 2014). The US Food and Drug Administration (FDA) has approved combination therapy (trametinib and dabrafenib) for advanced stage melanomas which cannot be removed by surgery and which have spread to the other sites of the body. Most recently a monoclonal antibody, nivolumab, was approved for advanced unresectable or metastatic melanoma; this is administered via intravenous infusion (www.fda.gov).

There are two types of treatment of AK: lesion- and field-directed. Lesion-directed treatment is suitable for treating single lesions found in grade $3 \mathrm{AK}$. In field-directed treatment, instead of single lesions, the entire field (containing $\geq 10$ AK lesions) is treated. Lesion-directed treatment includes cryosurgery, laser and curettage. Field-directed treatment includes photodynamic therapy, and topical chemo- and immunotherapy. FU, diclofenac sodium, imiquimod and ingenol mebutate have shown efficacy in the treatment of AK (see Section 5). Electrodessication and curettage is more commonly used in the USA for treatment of AK (de Berker et al., 2007; Zalaudek et al., 2014).

AIDS related KS is very effectively managed with systemic highly active antiretroviral therapy (HAART). Where there are only limited lesions and no involvement of internal organs, 
topical treatment with alitretinoin is considered (Cheng et al., 2008). For classic KS, radiotherapy is usually used although small lesions may be removed using cryotherapy and surgery. A combination of radiotherapy and chemotherapy is used to treat endemic KS. For those patients where KS is associated with immunosuppression, the medication regime may be altered to reduce immunosuppressant dose; if this is not effective then radiotherapy or chemotherapy are used (Antman and Chang, 2000).

\section{Drugs currently used for topical treatment of skin cancer and AK}

To date topical chemotherapy and immunotherapy have been used for the treatment of BCC and AK, and for limited cases of KS as noted above. Topical treatment is considered where the tumours are present in the top layers of the skin and also for palliative treatment. Drugs currently in use (Table 1, Figure 4) and preparations available (Table 2) are discussed in more detail below. A discussion of Photodynamic Therapy (PDT) is not included here as it requires light activation of a photosensitiser molecule; detailed reviews have recently been published elsewhere describing the treatment of AK with PDT (Christensen, 2014; Wiegell, 2015). For most topical actives, effective clearance of AK lesions involves tissue inflammation, necrosis, and skin discomfort; ulceration and crusting are also common. This section reviews topical therapies which are currently available as well as novel approaches to enhance skin delivery of these molecules. The physicochemical properties of molecules currently in use are summarised in Table 1. It is interesting to note that these are low molecular weight compounds with limited or no aqueous solubility. Although FU and diclofenac sodium are relatively more hydrophilic than the other molecules in Table 1 they are clearly capable of permeating intact as well as diseased skin. Compounds with balanced Log $\mathrm{P}$ values and $\mathrm{MW}<500$ are typically considered good candidates for (trans)dermal delivery in normal skin. Effective permeation of normal skin would appear to be a reasonable requirement for any new drug considered for topical management of cancer or AK. As the disease state is treated the barrier function is restored and treatment to full recovery will require that the active is able to permeate normal tissue.

\subsection{Diclofenac sodium}


Diclofenac has been used (as the sodium salt) for topical treatment of AK since the 1990s (Rivers and McLean, 1997). The rationale for the use of this non-steroidal anti-inflammatory drug is the over expression of the cycloxygenase-2 enzyme in AK and SCC compared with normal cells (Buckman et al., 1998). In studies with SCC cell cultures, the commercial preparation, Solaraze $\mathrm{TM}^{\mathrm{TM}}$, when diluted to $0.2-0.3 \%$ was observed to promote apoptosis in certain sensitive cell lines (Fecker et al. 2010). Although sodium hyaluronate is included in the commercial gel formulation (Solaraze $\AA$ ), the precise function of this component remains unclear (Table 2). Systemic absorption of diclofenac from Solaraze ${ }^{\mathrm{TM}}$ has been reported but comparator studies with other diclofenac formulations have not been conducted (MHRA, 2010). Published clinical studies have focussed on the cure rates for the formulation as well as tolerability (Martin and Stockfleth, 2012). Compared with other topical actives for AK, the dermatological side-effects for topical diclofenac are far less severe. Skin disposition and systemic absorption of diclofenac following application of Solaraze ${ }^{\mathrm{TM}}$ to AK lesions does not appear to have been investigated. However, given the long treatment times (Table 2), it may be beneficial to explore other strategies for the topical delivery of diclofenac to AK. Goh and Lane (2014) have recently reviewed the skin penetration characteristics of diclofenac and its salts, as well as the diverse formulation approaches investigated for topical delivery of the molecule in other therapeutic applications. The various methods explored to promote enhanced permeation of diclofenac include prodrugs, novel salt forms, supersaturation, use of skin penetration enhancers, microemulsions, lipid vesicles (including liposomes, Transferosomes ${ }^{\mathrm{TM}}$, lipid bicelles), solid lipid nanoparticles, liquid crystalline mesophases, cyclodextrins, nanosuspensions, films, patches, iontophoresis, laser microporation, ultrasound. For the chemical permeation strategies explored infinite doses of test formulations have largely been explored rather than finite doses thus there is considerable scope for further investigation with these methods. Microneedle (MN) mediated delivery of NSAIDs has recently been reported (McCrudden et al., 2014); this approach should allow higher drug loadings to be achieved in lesions and may also increase the number of candidate NSAIDs for topical AK treatment (McCrudden et al., 2014).

\subsection{Fluorouracil (FU)}

FU also known as 5-Fluorouracil (Figure 4) is approved for the topical treatment of AK, superficial BCC and Bowen's disease. The potential of FU in the management of AK emerged in the 1960s, with lesions disappearing in patients receiving systemic FU for other cancers (Falkson 
and Schulze, 1962). FU inhibits the enzyme responsible for synthesis of thymidine, one of the pyrimidine nucleosides of DNA. FU is only sparingly soluble in water (Moffat et al., 2004), and the physicochemical properties of the molecule are detailed in Table 1. Originally FU was formulated in hydrophilic petrolatum (Dillaha et al., 1963; 1965) or simple propylene glycol gel vehicles for topical application (Lorenzetti, 1979). Creams and solutions are currently available in a range of strengths (Table 2) with all formulations containing skin penetration enhancers. Only the 5\% preparations are used in the treatment of BCCs. One product (Actikerall®) for the treatment of AK also contains the keratolytic agent salicylic acid, as well as the penetration enhancer dimethyl sulphoxide.

Permeation of FU has been studied in vitro using porcine skin (Gao and Singh, 1997, 1998; Venuganti and Perumal, 2008, 2009; Hoppel et al., 2014) and human skin (Mollgaard et al., 1982; Bond and Barry, 1988; Goodman and Barry, 1988; Aungst et al., 1990; Levy et al., 2001; Singh et al., 2005; Copoví et al., 2006; Wiechers et al., 2012; Mutalik et al., 2014). Most of these studies were performed under infinite dose conditions, thus findings are not easily extrapolated to typical amounts of FU applied by patients. Levy et al. (2001a) compared the in vitro skin permeation of three "microsponge" or microsphere-based formulations containing $0.5 \% \mathrm{FU}$ with Efudex cream (5\% FU) using human cadaver skin. Formulations were dosed at $\sim 10 \mathrm{mg} / \mathrm{cm}^{2}$, and mass balance studies were also conducted. All of the microsponge formulations deposited greater amounts of FU in the skin (86-92\%) compared with the commercial formulation (54\%).

Dillaha et al. (1965) investigated the systemic absorption of FU in 39 patients following topical application to $\mathrm{AK}$ on the face, neck, hands or arms; a number of patients also had BCCs or SCCs. The FU was incorporated at $1 \%, 2 \%$ and $5 \%$ in hydrophilic petrolatum, and approximately $60 \mathrm{~g}$ of the ointment was applied to lesions over a two to four week period. The $5 \%$ preparation proved to be more successful for AK than the lower strengths and was efficacious in treating the SCCs. The amounts of radiolabelled FU in urine were also measured following a two to three-week application of the highest strength preparation to the face. Urinary measurements were taken $12 \mathrm{~h}$ after application of $1 \mathrm{~g}$ of the ointment to the entire face (excluding eyelid area) and neck. The mean systemic absorption was calculated to be $6 \%$ of the applied dose. Erlanger et al. (1970) investigated the absorption of FU from a 5\% ointment following application for $24 \mathrm{~h}$ to areas of healthy psoriatic skin, ulcerated skin or to a SCC. Amounts of FU applied ranged from $1.4-1.8$ $\mathrm{mg} / \mathrm{cm}^{2}$ and ${ }^{14} \mathrm{C}-\mathrm{FU}$ was measured in urine. For healthy skin the amount of FU excreted was reported to be $1.1 \%$ of the applied dose; corresponding values for psoriatic, ulcerated and SCC 
areas of skin were claimed to be $20 \%, 50 \%$ and $60 \%$. However the amount of formulation applied appears to be extremely high $\left(30-40 \mathrm{mg} / \mathrm{cm}^{2}\right)$ and cannot be compared with the amounts typically applied to the skin; in addition, only six patients were included in the study. Senff and co-workers (1988) investigated FU absorption following application of a solution of FU (0.5\%) to warts in 6 subjects; the treatment also contained DMSO and salicylic acid, and the warts were filed to enhance FU penetration. Plasma and urine analysis indicated that the mean amount of FU absorption was $<0.1 \%$. Dihydropyrimidine dehydrogenase (DPD) is responsible for catabolism of the pyrimidines, uracil and thymine, as well as FU. A rare case of FU toxicity has been reported in a patient with DPD deficiency following topical application of FU twice daily for one week in the management of BCC (Johnson et al., 1999). Levy et al. (2001b) reported the results of a study in AK patients who were randomised to apply either a $0.5 \%$ 'microsponge' FU formulation daily or a $5 \%$ FU formulation twice daily for 28 days. FU was detected in the plasma of patients for both groups but in a higher proportion of the subjects who used the 5\% FU; a similar trend was evident for urinary FU concentrations. Based on the limited number of subjects for whom FU urinary excretion values could be measured, systemic absorption was estimated as $0.6 \%$ for the $0.5 \%$ preparation and $2.4 \%$ for the $5 \%$ FU preparation.

\subsection{Imiquimod}

In 2004 a topical imiquimod cream (Aldara ${ }^{\circledR}$ ) was approved by the FDA for the treatment of superficial BCC and AK. However, the cream has also been used in some other skin diseases such as Bowen's disease, lentigo melanoma, SCC and cutaneous melanoma metastasis (Taveira and Lopez, 2011). Imiquimod is an immunomodulator and it triggers a cellular immune response via toll-like receptor 7 (TLR7). This response results in up-regulation of a number of cytokines ultimately resulting in apoptosis of neoplastic cells (Sligh, 2014). Structurally, imiquimod is an imidazoquiniline (Figure 4), and it was originally developed as part of a programme to identify potential anti-viral agents (Schon and Schon, 2007). Chollet et al. (1999) have outlined the development steps leading to an effective topical formulation of imiquimod which is practically insoluble in water. Isostearic acid was selected as the primary solvent for the molecule, and the other formulation components of this oil-in-water cream include emulgents, viscosity modifiers and preservatives. A lower strength preparation (3.75\% imiquimod, Zyclara®) is also available for 
treatment of AK lesions on specific body sites. The lower strength preparation may be used daily, unlike Aldara ${ }^{\circledR}$, and may also be applied over larger areas of skin (Table 2).

Systemic levels of imiquimod have not been detected following application of Aldara ${ }^{\circledR}$ to genital/perianal areas for the treatment of warts but low levels of the drug were found in the urine (Owens et al., 1998). A bioadhesive patch formulation for delivery of imiquimod was designed and evaluated by Donnelly and co-workers (2006) using a poly(methyl vinyl ether-co-maleic anhydride) co-polymer. Drug loadings of $4.8,9.5$ and $12.5 \mathrm{mg} / \mathrm{cm}^{2}$ were prepared and evaluated for their release characteristics; however drug permeation characteristics in skin were not determined. De Paula et al. (2008) have reported the in vitro permeation of imiquimod in dermatomed porcine skin $(500 \mu \mathrm{m})$ in Franz cells from propylene glycol:water vehicles, with either urea or salicylic acid also included. Drug concentrations in the vehicles ranged from $50-750 \mu \mathrm{g} / \mathrm{ml}$ with $1 \mathrm{ml}$ of each formulation applied to an effective diffusional area of $\sim 0.8 \mathrm{~cm}^{2}$. Although the amount of drug which penetrated to the receptor compartment was much lower than the amounts retained in the skin, the authors did not determine the exact percentage of the dose which permeated. Pre-treatment of excised porcine skin with an erbium-doped yttrium aluminium garnet (Er:YAG) laser for enhanced delivery of imiquimod in vitro was reported by Lee et al. (2011b). Laser wavelength, pulse duration and energy applied were respectively, $2940 \mathrm{~nm}, 400 \mu$ s at either 2 or $3 \mathrm{~J} / \mathrm{cm}^{2}$. Maximum cumulative amounts of imiquimod which permeated in Franz cells after $48 \mathrm{~h}$ were $\sim 20 \mu \mathrm{g} / \mathrm{cm}^{2}$ for the laser treatment compared with $<1 \mu \mathrm{g} / \mathrm{cm}^{2}$ for the control. Control values are consistent with the data reported in the earlier study of De Paula et al. (2008). However, infinite dose conditions were employed $\left(500 \mu \mathrm{l}\right.$ of a $0.1 \% \mathrm{w} / \mathrm{v}$ formulation applied to $\sim 0.8 \mathrm{~cm}^{2}$ of tissue). Iontophoresis as a delivery modality for imiquimod is the subject of a published US Patent Application (US 2010/0331812 A1), although only data for rat models are disclosed. Although coated MN have been investigated for co-delivery of imiquimod and the H1N1 subunit vaccine (Weldon et al., 2012), they do not appear to have been considered for targeting of imiquimod to AK or cancerous lesions.

\subsection{Ingenol mebutate}

Ingenol mebutate (IM) is a macrocyclic diterpene ester which was originally isolated from an indigenous Australian plant, Euphorbia peplus (Siller et al., 2009). The precise mechanism of action of IM is not known, however it promotes rapid lesion necrosis and neutrophil-mediated 
cellular cytotoxicity (Rosen et al., 2012). Modulation of protein kinase C isoforms has also been observed in tumour cells in vitro (Kedei et al., 2004). Currently, gel formulations are available in two strengths for the treatment of AK, the lower for the face and the higher for the extremities (Table 2). Treatment is typically for three consecutive days which is much shorter when compared with other topical AK therapies.

Erlendsson and co-authors (2015) have recently reported the effects of ablative laser treatment on IM disposition in porcine skin in vitro. Microscopic ablated areas were generated by application of either 11.2 or $128 \mathrm{~mJ}$ to excised areas of skin. Control and laser-treated skin samples were mounted in Franz cells of diffusion area $0.64 \mathrm{~cm}^{2}$, and the amount of formulation applied in the donor chamber was $10 \mu \mathrm{L} / \mathrm{cm}^{2}$. Penetration of IM to the receptor fluid was not observed in the intact skin samples but up to $21 \%$ of the applied dose was determined in the laser treated skin samples. Mass balance studies indicated that $57 \%$ of the applied dose remained in or on the skin at the end of the permeation experiment; for laser treated skin the maximal values in epidermis and dermis, respectively, were $62 \%$ and $18 \%$ of the applied dose. The presence of isopropyl alcohol in the IM formulation is surprising as it is likely to exacerbate the skin irritation associated with tissue necrosis.

\subsection{Topical retinoids}

The effects of Vitamin A analogues (retinoids) on hyperkeratinisation, inflammation and immunomodulation following topical or oral application were demonstrated more than three decades ago (Elias and Williams, 1981). Retinoids work by interacting with retinoic acid receptors (RARs) or retinoic $\mathrm{X}$ receptors (RXRs) and activating genes that contain retinoic acid response elements (RAREs) or retinoic X response elements (RXREs). Effects on gene expression are also possible by inhibition of specific transcription factors (Michel et al., 1998).. First generation retinoids evaluated for topical treatment of $\mathrm{AK}$ include tretinoin (all trans-retinoic acid) and isotretinoin (13-cis-retinoic acid); the third geration retinoid, adapalene, has also been investigated (Kligman et al., 1991; Alirezai et al., 1994; Kang et al., 2003). Tretinoin and adapalene have also been used to treat AK or NMSC in conjunction with laser ablation therapy (Bercovitch, 1987; Kang et al., 2003; Prens et al., 2013; Pearce and Williford, 2014). Additionally, topical tretinoin has been investigated for its ability to reduce the risk of BCC and SCC but results to date do not support a 
chemoprevention role (Weinstock et al., 2012). Overall evidence for efficacy of topical retinoids in the management of $\mathrm{AK}$ is lacking and thus they remain unapproved for therapy of this condition. Alitretinoin (9-cis-retinoic acid) is a first generation retinoid which activates both RARs and RXRs, ultimately resulting in modulation of genes responsible for cell proliferation and differentiation. It is used for the management of skin lesions in patients with AIDS-related KS, but not where systemic $\mathrm{KS}$ is indicated. Only one formulation of alitretinoin is currently available which is licensed both in Europe and the United States (Table 2).

\section{Summary and conclusions}

The occurrence of skin cancer and AK is increasing in Caucasian populations. Topical therapy has an established role in the management of specific NMSCs and AK, particularly for improved skin appearance and quality of life for patients. To date, only a few low molecular weight actives have been available for direct application to these lesions. Surprisingly, some of the formulations currently available contain excipients which are likely to exacerbate the skin conditions being treated. Treatment times are overly long for other preparations, and there is scope to address this problem using alternative formulation strategies. The advent of skin poration approaches such as MN delivery clearly offers the possibility of more effective drug targeting to diseased skin but few studies have been carried out to date. Our understanding of the barrier properties of skin in these conditions remains limited despite the availability of advanced spectroscopic and biomechanical tools for skin examination. This, in part, reflects the inter-patient differences associated with skin diseases, and the variable clinical presentation of lesions. Finally, new chemical entities for the topical management of these skin conditions do not appear to be emerging despite the low number of actives currently in use. 


\section{References}

Ackerman, A.B., 1985. Histologic features of Kaposi's sarcoma and simulators of it. In: Kaposi's sarcoma. Edited by D Cerimele. Spectrum Publications Inc, New York, pp. 71-79.

Alirezai, M., Dupuy, P., Amblard, P., Kalis, B., Souteyrand, P., Frappaz, A., Sendagorta, E., 1994.

Clinical evaluation of topical isotretinoin in the treatment of actinic keratoses. J. Am. Acad. Dermatol. 30, 447-51.

Antman K, Chang Y., 2000. Kaposi's sarcoma. N. Engl. J. Med. 342, 1027-38.

Aungst, B.J., Blake, J A., Hussain, M.A., 1990. Contributions of drug solubilization, partitioning, barrier disruption, and solvent permeation to the enhancement of skin permeation of various compounds with fatty acids and amines. Pharm. Res. 7, 712-8.

Balch, C.M., Gershenwald, J.E., Soong, S.J., Thompson, J.F., Atkins, M.B., Byrd, D.R., Buzaid, A.C., Cochran, A.J., Coit, D.G., Ding, S., Eggermont, A.M., Flaherty, K.T., Gimotty, P.A., Kirkwood, J.M., McMasters, K.M., Mihm, M.C. Jr., Morton, D.L., Ross, M.I., Sober, A.J., Sondak, V.K., 2009. Final version of 2009 AJCC melanoma staging and classification. J. Clin. Oncol. 27, 6199-206.

Baroni, A., Buommino, E., De Gregorio, V., Ruocco, E., Ruocco, V., Wolf,, R. 2012. Structure and function of the epidermis related to barrier properties. Clin. Dermatol. 30, 257-62

Bataille, V., 2013. Sun exposure, sunbeds and sunscreens and melanoma. What are the controversies? Curr. Oncol. Rep., 15, 526-532.

Bath-Hextall, F., Leonardi-Bee, J., Smith, C., Meal, A., Hubbard, R., 2007. Trends in incidence of skin basal cell carcinoma. Additional evidence from a UK primary care database study. Int. J. Cancer. 121, 2105-8.

Benson, H.A.E., 2012. Skin structure, function, and permeation, in Topical and Transdermal Drug Delvery: Principles and Practice, H.A.E. Benson and A.C. Watkinson, Editors. John Wiley \& Sons, Inc.: New Jersey. p. 3-22. 
Bercovitch, L., 1987. Topical chemotherapy of actinic keratoses of the upper extremity with tretinoin and 5-fluorouracil: a double-blind controlled study. Br. J. Dermatol. 116, 549-52.

Bond, J.R., Barry, B.W., 1988 Damaging effect of acetone on the permeability barrier of hairless mouse skin compared with human skin. Int. J. Pharm. 41, 91-93.

Buckman, S.Y., Gresham, A., Hale, P, Hruza, G., Anast, J., Masferrer, J., Pentland, A.P., 1998. COX-2 expression is induced by UVB exposure in human skin: implications for the development of skin cancer. Carcinogenesis 19, 723-9.

Byrd-Miles, K., Toombs, E.L., Peck, G.L., 2007. Skin cancer in individuals of African, Asian, Latin-American, and American-Indian descent: differences in incidence, clinical presentation, and survival compared to Caucasians. J. Drugs Dermatol. 6, 10-6.

Cheng,. C, Michaels, J., Scheinfeld, N., 2008. Alitretinoin: a comprehensive review. Expert Opin. Investig. Drugs. 17, 437-43.

Christensen, E., 2014. Spotlighting the role of photodynamic therapy in cutaneous malignancy: an update and expansion. Dermatol. Surg. 40, 589.

Cockerell, C.J., 2000. Histopathology of incipient intraepidermal squamous cell carcinoma ("actinic keratosis"). J. Am. Acad. Dermatol., 42(1, Part 2): p. S11-S17.

Copoví, A., Díez-Sales, O., Herráez-Domínguez, J.V., Herráez-Domínguez, M., 2006. Enhancing effect of alpha-hydroxyacids on "in vitro" permeation across the human skin of compounds with different lipophilicity. Int. J. Pharm. 314, 31-6.

Curtin, J.A., Fridlyand, J., Kageshita, T., Patel, H.N., Busam, K.J., Kutzner, H., Cho, K.H., Aiba, S., Bröcker, E.B., LeBoit, P.E., Pinkel, D., Bastian, B.C. 2005. Distinct sets of genetic alterations in melanoma. N. Engl. J. Med. 353, 2135-47.

de Berker, D., McGregor J.M., Hughes B.R., 2007. Guidelines for the management of actinic keratoses. Br. J. Dermatol. 156: p. 222-230., 
De Paula, D., Martins, C.A., Bentley, M.V., 2008. Development and validation of HPLC method for imiquimod determination in skin penetration studies. Biomed. Chromatogr. 22, 1416-23.

Dillaha, C.J., Jansen, G.T., Honeycutt, W.M., Holt, G.A., 1965. Further studies with topical 5fluorouracil. Arch Dermatol. 92, 410-7.

Donnelly, R.F., McCarron, P.A., Zawislak, A.A., Woolfson, D., 2006. Design and physicochemical characterisation of a bioadhesive patch for dose-controlled topical delivery of imiquimod. Int. J. Pharm. 307, 318-325.

Elias, P.M., Williams, M.L., 1981. Retinoids, cancer and the skin. Arch. Dermatol. 117, 160-8.

Elias, P.M., 1988. Structure and function of the stratum corneum permeability barrier. Drug Dev. Res. 13, 97-105.

Elias, P.M., Cooper, E.R., Korc, A., Brown, B.E., 1981. Percutaneous transport in relation to stratum corneum structure and lipid composition J. Invest. Dermatol. 76, 297-301.

Erlanger, M., Martz, G., Ott, F., Storck, H., Rieder, J., Kessler, S., 1970. Cutaneous absorption and urinary excretion of 6-14C-5-fluorouracil ointment applicated in an ointment to healthy and diseased human skin. Dermatologica.140 (Suppl 1)_ 7-14.

Erlendsson, A.M., Taudorf, E.H., Eriksson, A.H., Haak, C.S., Zibert, J.R., Paasch, U., Anderson, R.R., Haedersdal, M., 2015. Ablative fractional laser alters biodistribution of ingenol mebutate in the skin. Arch. Dermatol. Res. 2015. In Press.

Falkson, G., Schulz, E.J. 1962. Skin changes in patients treated with 5-fluorouracil. Br. J. Dermatol. 74, 229-36.

Fecker, L.F., Stockfleth, E., Braun, F.K., Rodust, P.M., Schwarz, C., Köhler, A., Leverkus, M., Eberle, J., 2010. Enhanced death ligand-induced apoptosis in cutaneous SCC cells by treatment 
with diclofenac/hyaluronic acid correlates with downregulation of c-FLIP. J. Invest. Dermatol. 130, 2098-109.

Fuchs, A., Marmur, E., 2007. The kinetics of skin cancer: progression of actinic keratosis to squamous cell carcinoma. Dermatol. Surg. 33, 1099-101.

Gao, S., Singh, J., 1997. Mechanism of transdermal transport of 5-fluorouracil by terpenes: carvone, 1,8-cineole and thymol. Int. J. Pharm. 154, 67-77.

Gao, S., Singh, J., 1998. Effect of oleic acid/ethanol and oleic acid/propylene glycol on the in vitro percutaneous absorption of 5-fluorouracil and tamoxifen and the macroscopic barrier property of porcine epidermis. Int. J. Pharm. 165, 45-55.

Goh, C.F., Lane, M.E., 2014. Formulation of diclofenac for dermal delivery. Int. J. Pharm. 473, 607-616.

Glaxo Smith Kline, Inc. Alitretinoin. Product Monograph. April, 2013. Pp.1-36.

Goldenberg, G., 2010. Histopathology of skin cancer. In Managing Skin Cancer. E. Stockfleth. T. Rosen, S. Schumaak (Eds) Springer Verlag Berlin Heidleberg. Pp.17 - 35.

Goodman, M., Barry, B.W., 1988. Action of penetration enhancers on human skin as assessed by the permeation of model drugs 5-fluorouracil and estradiol. I. Infinite dose technique. J. Invest. Dermatol. 91, 323-327.

Halaban, R., Herbert, D.N., Fisher, D.E., 2003. Biology of melanocytes. In: Fitzpatrick's Dermatology in General Medicine. McGraw Hill, New York. Pp. 127-148.

Hoppel, M., Mahrhauser, D., Stallinger, C., Wagner, F., Wirth, M., Valenta, C., 2014. Natural polymer-stabilized multiple water-in-oil-in-water emulsions: a novel dermal drug delivery system for 5-fluorouracil. J. Pharm. Pharmacol. 66, 658-67.

http://www.fda.gov/Drugs/InformationOnDrugs/ApprovedDrugs/ucm381451.htm 
Ibrahim, S.F., Brown, M.D., 2009. Actinic keratoses: a comprehensive update. J. Clin. Aesthet. Dermatol. 2, 43-8.

Ito, S., Wakamatsu K., 2003., Quantitative analysis of eumelanin and pheomelanin in humans, mice, and other animals: a comparative review. Pigment Cell Res. 16, 523-531.

Jerant, A.F., Jhonson, J.T., Sheridan, C.D., Caffrey, T.J., 2000. Early detection and treatment of skin cancer. Am. Fam. Physician, 62, 357-368.

Johnson, M.R., Hageboutros, A., Wang, K., High, L., Smith, J.B., Diasio, R.B., 1999. Lifethreatening toxicity in a dihydropyrimidine dehydrogenase-deficient patient after treatment with topical 5-fluorouracil. Clin. Cancer Res. 5, 2006-11.

Kang, S., Goldfarb, M.T., Weiss, J.S., Metz, R.D., Hamilton, T.A., Voorhees, J.J., Griffiths, C.E. 2003. Assessment of adapalene gel for the treatment of actinic keratoses and lentigines: a randomized trial. J. Am. Acad. Dermatol. 49, 83-90.

Kligman, A.L., Thorne, E.G., 1991. Topical therapy of actinic keratoses with tretinoin. In: Marks R, editor. Retinoids in cutaneous malignancy. Oxford, UK: Blackwell Scientific Publications, pp. 6673.

Kedei, N., Lundberg, D.J., Toth, A., Welburn, P., Garfield, S.H., Blumberg, P.M., 2004. Characterization of the interaction of ingenol 3-angelate with protein kinase C. Cancer Res. 64, 3243-3255.

Kudchadkar, R., Weber J.S., 2011. Melanomas and other cutaneous malignancies, in Handbook of Cancer Chemotherapy, R.T. Skeel and S.N. Khleif, Editors. Lippincott Williams and Wilkins: London. p. 277-297.

Lee, J.H., Choi, J.W., Kim, Y.S., 2011a. Frequencies of BRAF and NRAS mutations are different in histological types and sites of origin of cutaneous melanoma: a meta-analysis. Br. J. Dermatol. $164,776-84$. 
Lee, W.R., Shen, S.C., Al-Suwayeh, S.A., Yang, H.H., Yuan, C.Y., Fang, J.Y., 2011b. Laserassisted topical drug delivery by using a low-fluence fractional laser: imiquimod and macromolecules. J. Control. Release. 153, 240-8.

Leo Pharma, Inc. Picato. Product Monograph. January, 2013. Pp. 1-26.

Levy, S., Furst, K., Chern, W., 2001a. A comparison of the skin permeation of three topical $0.5 \%$ fluorouracil formulations with that of a $5 \%$ formulation. Clin. Ther. 23, 901-7.

Levy, S., Furst, K., Chern, W., 2001b. A pharmacokinetic evaluation of $0.5 \%$ and $5 \%$ fluorouracil topical cream in patients with actinic keratosis. Clin. Ther. 23, 908-20.

Lorenzetti, O.J. 1979. Propylene glycol gel vehicles. Cutis. 23, 747, 750.

Lovly, C.M., Dahlman, K.B., Fohn, L.E., Su, Z., Dias-Santagata, D., Hicks, D.J., Hucks, D., Berry, E., Terry, C., Duke, M., Su, Y., Sobolik-Delmaire, T., Richmond, A., Kelley, M.C., Vnencak-Jones, C.L., Iafrate, A.J., Sosman, J., Pao, W., 2012. Routine multiplex mutational profiling of melanomas enables enrollment in genotype-driven therapeutic trials. PLoS One. 7, e35309.

Madan, V., 2009. Environmental risk factors for non-melanoma skin cancers, in Non-Surgical Treatment of Keratinocyte, G.B.E. Jemec, D. Meich, and L. Kemeny, Editors. Springer: London, New York. p. 39-50.

Maddodi, N., Setaluri V., 2008. Role of UV in cutaneous melanoma. Photochem. Photobiol., 84, 528-536.

Markovic, S.N., Erickson, L.A., Rao, R.D., Weenig, R.H., Pockaj, B.A., Bardia, A., Vachon, C.M., Schild, S.E., McWilliams, R.R., Hand, J.L., Laman, S.D., Kottschade, L.A., Maples, W.J., Pittelkow, M.R., Pulido, J.S., Cameron, J.D., Creagan, E.T.; Melanoma Study Group of the Mayo Clinic Cancer Center., 2007. Malignant melanoma in the $21^{\text {st }}$ century, part 1: epidemiology, risk factors, screening, prevention, and diagnosis. Mayo Clin. Proc. 82, 364-80. 
Martin, G.M., Stockfleth, E. 2012. Diclofenac sodium 3\% gel for the management of actinic keratosis: 10+ years of cumulative evidence of efficacy and safety. J. Drugs Dermatol. 11, 600-8.

Maverakis, E., Cornelius, L.A., Bowen, G.M., Phan, T., Patel, F.B., Fitzmaurice, S., He, Y., Burrall, B., Duong, C., Kloxin, A.M., Sultani, H., Wilken, R., Martinez, S.R., Patel, F., 2015. Metastatic Melanoma - A Review of Current and Future Treatment Options. Acta Derm. Venereol. 95, 516-24.

McCormack, C.J., Kelly, J.W., Dorevitch, A.P., 1997. Differences in age and body site distribution of the histological subtypes of basal cell carcinoma. A possible indicator of differing causes. Arch Dermatol. 133, 593-6.

McCrudden, M.T., Alkilani, A.Z., McCrudden, C.M., McAlister, E., McCarthy, H.O., Woolfson, A.D., Donnelly, R.F. 2014. Design and physicochemical characterisation of novel dissolving polymeric microneedle arrays for transdermal delivery of high dose, low molecular weight drugs. J Control. Release. 180, 71-80.

McGrath, J.A., Eady, R.A.J., Pope, F.M., 2008. Anatomy and organization of human skin, in Rook's Textbook of Dermatology, T. Burns, et al., Editors. Blackwell Publishing, Inc. p. 45-128.

McGuire, J.F., Ge, N.N., Dyson, S., 2009. Nonmelanoma skin cancer of the head and neck I: histopathology and clinical behavior. Am. J. Otolaryngol., 30, 121-133.

Meyer, L.J., Zone, J.H., 1994. Genetics of cutaneous melanoma. J. Invest. Dermatol. 103,( Suppl 5), $112 \mathrm{~S}-116$.

Michaels, S., Chandrasekaran, S.K., Shaw, J.E., 1975. Drug permeation through human skin: theory and in vitro experimental measurement AIChE J. 21, 985-996.

Michel, S., Jomard, A., Démarchez, M., 1998. Pharmacology of adapalene. Br. J. Dermatol. 139 (Suppl. 52), 3-7.

Moffat, A.C., Osselton, M.D., Widdop, B., Watts, J. (Eds). 2011. Clarke's Analysis of Drugs and Poisons. Fourth edition. Pharmaceutical Press. London, UK. 2473 pages. 
Mollgaard, B ., Hoelgaard, A., Bundgaard, H., 1982. Pro-drugs as drug delivery systems XXIII. Improved dermal delivery of 5-fluorouracil through human skin via $\mathrm{N}$-acyloxymethyl pro-drug derivatives. Int. J. Pharm. 12, 153-162.

Motley, R.J., Preston, P.W., Lawrence, C.M., 2002. Multi-professional guidelines for the management of the patient with primary cutaneous squamous cell carcinoma. Br. J. Dermatol. 146, $18-25$.

Murphy, G.M., 2009. From precursor to cancer: field cancerization and the opportunities for therapy, in: Non-Surgical Treatment of Keratinocyte Skin Cancer, G.B.E. Jemec, D. Meich, and L. Kemeny, Editors. Springer: London, New York. p. 1-7.

Mutalik, S., Shetty, P.K., Kumar, A., Kalra, R., Parekh, H.S., 2014. Enhancement in deposition and permeation of 5-fluorouracil through human epidermis assisted by peptide dendrimers. Drug Deliv. $21,44-54$.

O'Neil, M.J., ed. 2006. The Merck Index: An Encyclopedia of Chemicals, Drugs, and Biologicals. 14th ed. New Jersey: Merck. .

Owens, M.L., Bridson, W.E., Smith, S.L., Myers, J.A., Fox, T.L., Wells, T.M., 1998. Percutaneous penetration of Aldara cream, 5\% during the topical treatment of genital and perianal warts. Prim. Care Update Ob. Gyns. 5, 151.

Park, H.Y., Kosmadaki M., Yaar M., Gilchrest B.A., 2009. Cellular mechanisms regulating human melanogenesis. Cell. Mol. Life Sci. 66, 1493-1506.

Pearce, D.J., Williford, P.M., 2014. Another approach to actinic keratosis management using nonablative fractional laser. J. Dermatolog. Treat. 25, 298.

Prens, S.P., de Vries, K., Neumann, H.A., Prens, E.P., 2013. Non-ablative fractional resurfacing in combination with topical tretinoin cream as a field treatment modality for multiple actinic keratosis: a pilot study and a review of other field treatment modalities. J. Dermatolog. Treat. 24, 227-31. 
Raposo, G., Marks, M.S., 2002. The dark side of lysosome-related organelles: specialization of the endocytic pathway for melanosome biogenesis. Traffic. 3, 237-248.

Ratner, D., Peacocke M., Zhang H., Ping X.L., Tsou H.C., 2001. UV-specific p53 and PTCH mutations in sporadic basal cell carcinoma of sun-exposed skin. J. Am. Acad. Dermatol. 44, 293297.

Ries, L.A., Wingo, P.A., Miller, D.S., Howe, H.L., Weir, H.K., Rosenberg, H.M., Vernon, S.W., Cronin, K., Edwards, B.K., 2000. The annual report to the nation on the status of cancer, 19731997, with a special section on colorectal cancer. Cancer. 88, 2398-424.

Rivers, J.K., McLean, D.I., 1997. An open study to assess the efficacy and safety of topical 3\% diclofenac in a $2.5 \%$ hyaluronic acid gel for the treatment of actinic keratoses. Arch. Dermatol. 133, 1239-42.

Rosen, R.H., Gupta, A.K.,Tyring, S.K., 2012. Dual mechanism of action of ingenol mebutate gel for topical treatment of actinic keratoses: rapid lesion necrosis followed by lesion-specific immune response. J. Am. Acad. Dermatol. 66, 486-93.

Röwert-Huber, J., Patel, M.J., Forschner, T., Ulrich, C., Eberle, J., Kerl, H., Sterry, W., Stockfleth, E., 2007. Actinic keratosis is an early in situ squamous cell carcinoma: a proposal for reclassification. Br. J. Dermatol. 156 (Suppl. 3) 8-12.

Schwartz, R.A., 2004. Keratoacanthoma: a clinico-pathologic enigma. Dermatol. Surg. 30(2 Pt 2) 326-33.

Siller, G., Gebauer, K., Welburn, P., Katsamas, J., Ogbourne, S.M., 2009. PEP005 (ingenol mebutate) gel, a novel agent for the treatment of actinic keratosis: results of a randomized, doubleblind, vehicle-controlled, multicentre, phase IIa study. Australas. J. Dermatol. 50, 16-22. 
Singh, B.N., Singh, R.B., Singh, J., 2005. Effects of ionization and penetration enhancers on the transdermal delivery of 5-fluorouracil through excised human stratum corneum. Int. J. Pharm. 298, 98-107.

Sligh, J.E. Jr., 2014. New therapeutic options for actinic keratosis and basal cell carcinoma. Semin Cutan. Med. Surg. 33(4 Suppl) S76-80.

Suhonen, T.M., Bouwstra, J.A., Urtti, A., 1999. Chemical enhancement of percutaneous absorption in relation to stratum corneum structural alterations. J. Control. Release. 59, 149-161.

Taveira, S.F., Lopez, R.F.V., 2011. Topical administration of anticancer drugs for skin cancer treatment in Skin Cancers - Risk Factors, Prevention and Therapy, C.A.L. Porta, Editor. InTech.. 247-272.

Telfer, N.R., Colver G.B., Morton C.A., 2008. Guidelines for the management of basal cell carcinoma. Br. J. Dermatol. 159, 35-48.

Venuganti, V.V., Perumal, O.P., 2008. Effect of poly(amidoamine) (PAMAM) dendrimer on skin permeation of 5-fluorouracil. Int. J. Pharm. 361, 230-8.

Walters, K.A., Abdalghafor, H.M., Lane, M.E., 2012. The human nail - barrier characterisation and permeation enhancement. Int. J. Pharm. 435, 10-21.

Weinstock, M.A., Bingham, S.F., Digiovanna, J.J., Rizzo, A.E., Marcolivio, K., Hall, R., Eilers, D., Naylor, M., Kirsner, R., Kalivas, .J, Cole, G., Vertrees, J.E.; Veterans Affairs Topical Tretinoin Chemoprevention Trial Group., 2012. Tretinoin and the prevention of keratinocyte carcinoma (Basal and squamous cell carcinoma of the skin): a veterans affairs randomized chemoprevention trial. J. Invest. Dermatol. 132, 1583-90

Weldon, W.C., Zarnitsyn, V.G., Esser, E.S., Taherbhai, M.T., Koutsonanos, D.G., Vassilieva, E.V., Skountzou, I., Prausnitz, M.R., Compans, R.W., 2012. Effect of adjuvants on responses to skin immunization by microneedles coated with influenza subunit vaccine. PLoS One. 7, e41501. 
Wertz, P.W. and Downing D.T., 1989. Stratum corneum: biological and biochemical considerations, in Transdermal Drug Delivery: Developmental Issue and Research Initiatives, J. Hadgraft and R.H. Guy, Editors. Marcel Dekker, Inc.: New York. p. 1-22.

Wiechers, J.W., Watkinson, A.C., Cross, S.E., Roberts, M.S. 2012. Predicting skin penetration of actives from complex cosmetic formulations: an evaluation of inter formulation and inter active effects during formulation optimization for transdermal delivery. Int J Cosmet Sci. 34, 525-35.

Wiegell, S.R., 2015. Update on photodynamic treatment for actinic keratosis. Curr. Probl. Dermatol. 46, 122-8.

Wood, E.J., Bladon P.T., 1985. The human skin. Studies on Biology. Vol. 164. Edward Arnold London. 68.

Zalaudek, I., Piana S., Moscarella E., Longo C., Zendri E., Castagnetti F., Pellacani G., Lallas A., Argenziano, G., 2014. Morphologic grading and treatment of facial actinic keratosis. Clinics in Dermatology, 32, 80-87. 


\section{LIST OF FIGURES}

Figure 1: Diagrammatic representation of: A. layers of human epidermis, B. 'brick and mortar' organisation of the SC, and C. organisation of aqueous and lipid domains in the intercellular bilayer region

Figure 2: Melanocytes and migration of melanosomes through the dendritic extensions to the surrounding keratinocytes (Adapted from Wood and Bladon, 1985)

Figure 3: Stages of development of SCC from AK and invasive SCC. (1) Atypical keratinocytes and (2) increased number of squamous cells containing enlarged, atypical and pleomorphic nuclei (Adapted from Cockerell, 2000)

Figure 4. Drugs currently used for topical treatment of skin cancer and AK. 


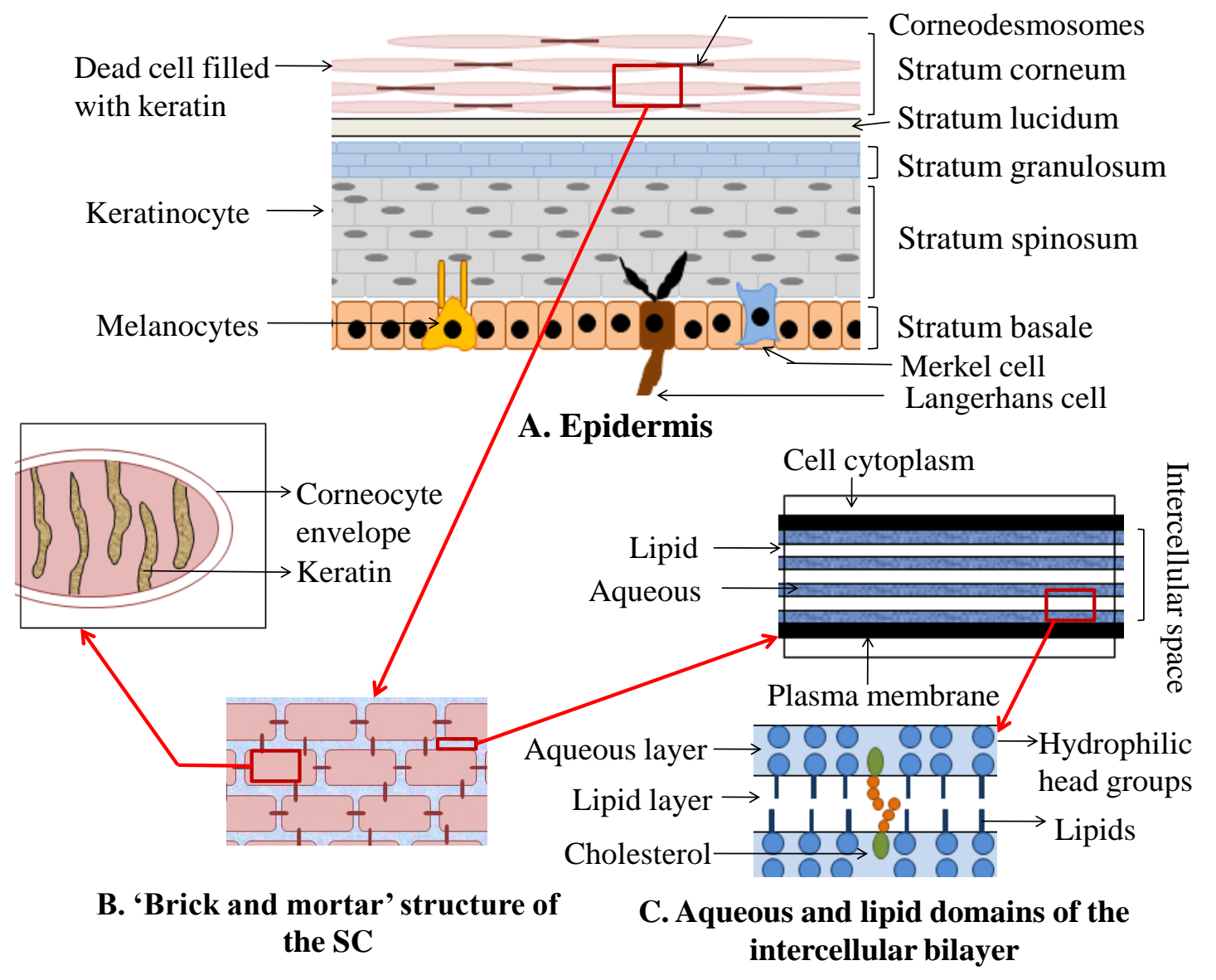

Figure 1: Diagrammatic representation of: A. layers of human epidermis, B. 'brick and mortar' organisation of the SC, and $\mathrm{C}$. organisation of aqueous and lipid domains in the intercellular bilayer region 


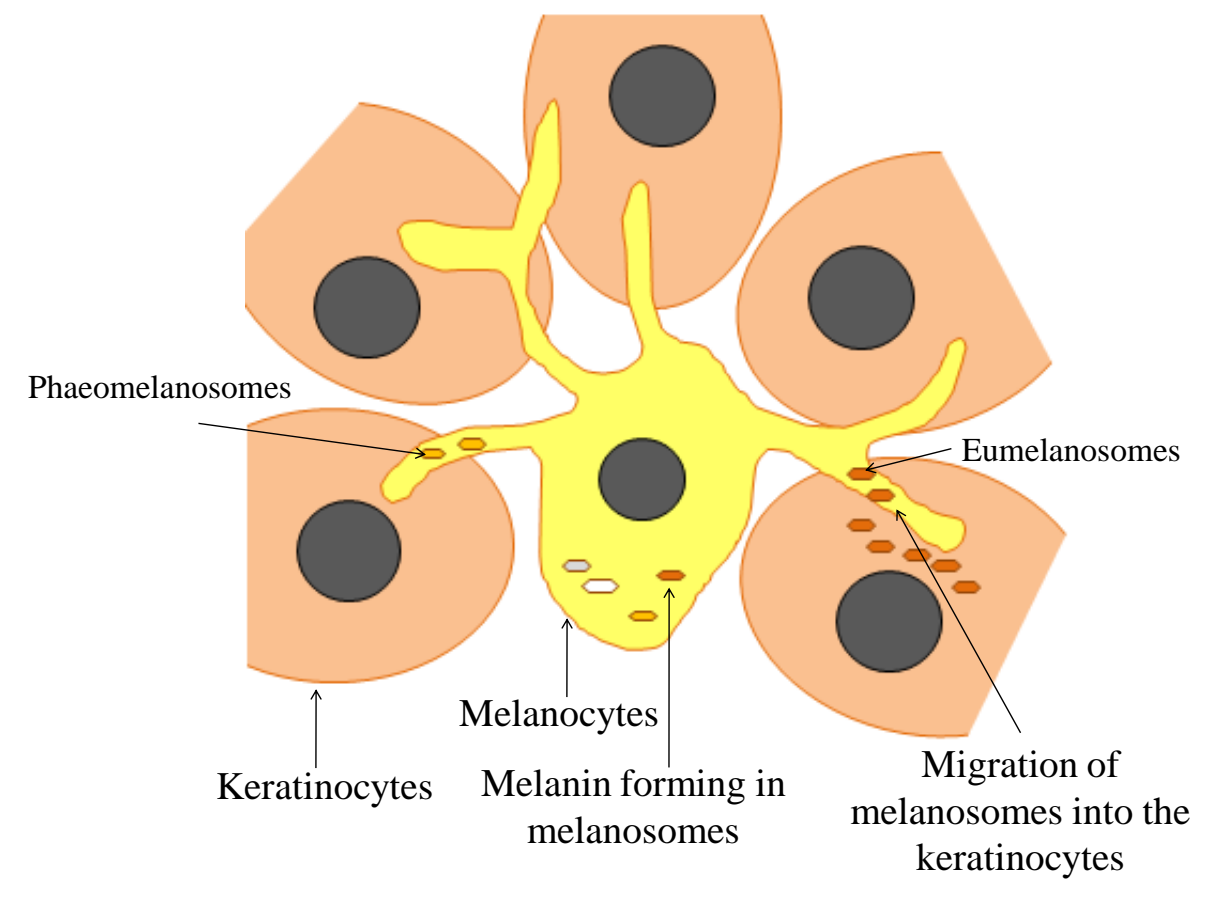

Figure 2: Melanocytes and migration of melanosomes through the dendritic extensions to the surrounding keratinocytes (Adapted from Wood and Bladon, 1985) 


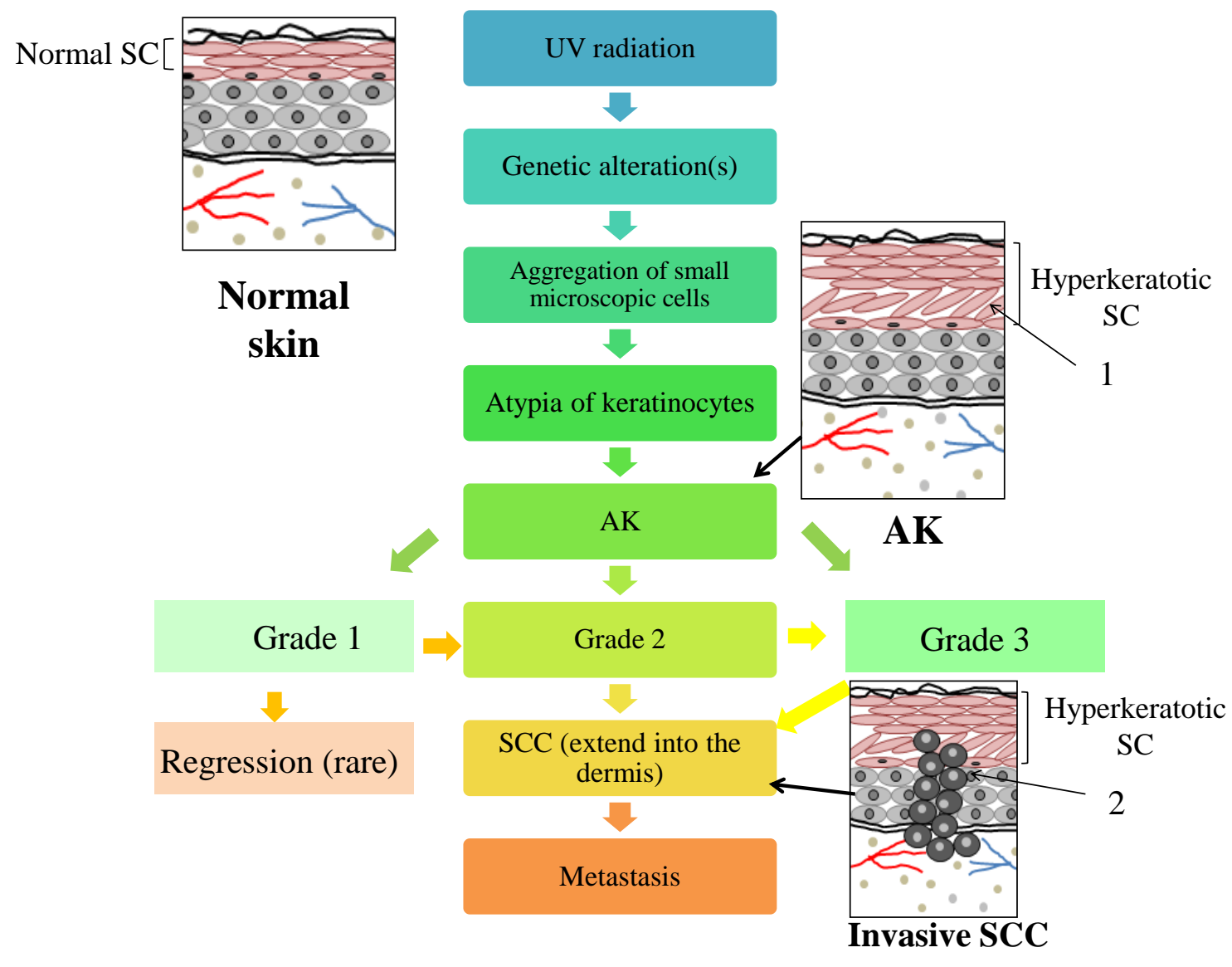

Figure 3: Stages of development of SCC from AK and invasive SCC. (1) Atypical keratinocytes and (2) increased number of squamous cells containing enlarged, atypical and pleomorphic nuclei (adapted from Cockerell, 2000) 


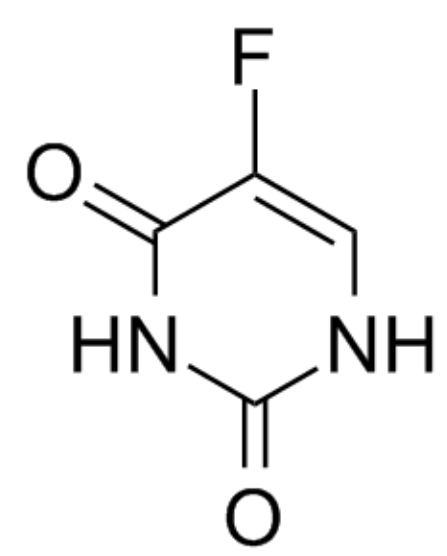

5-Flurouracil

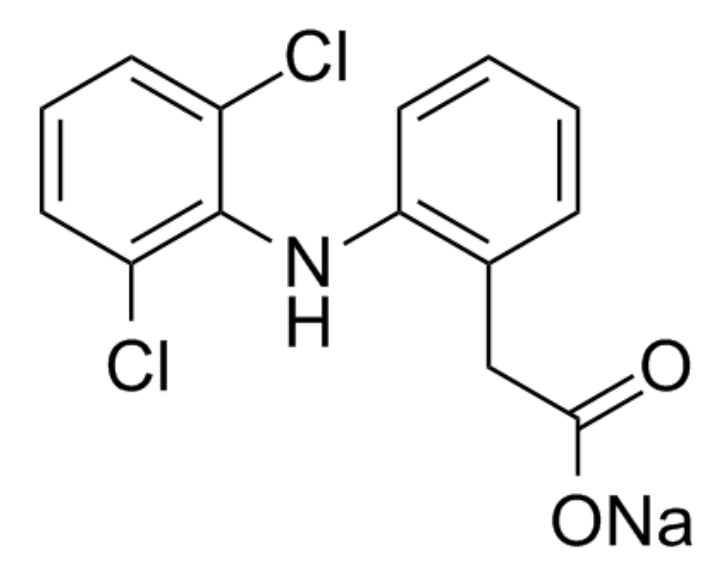

Diclofenac sodium

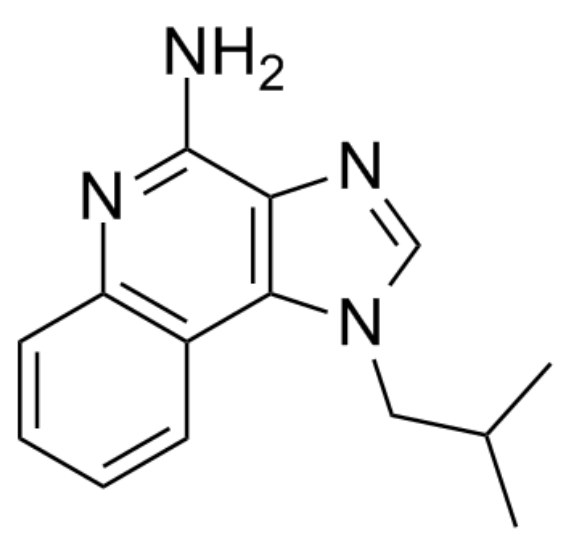

Imiquimod

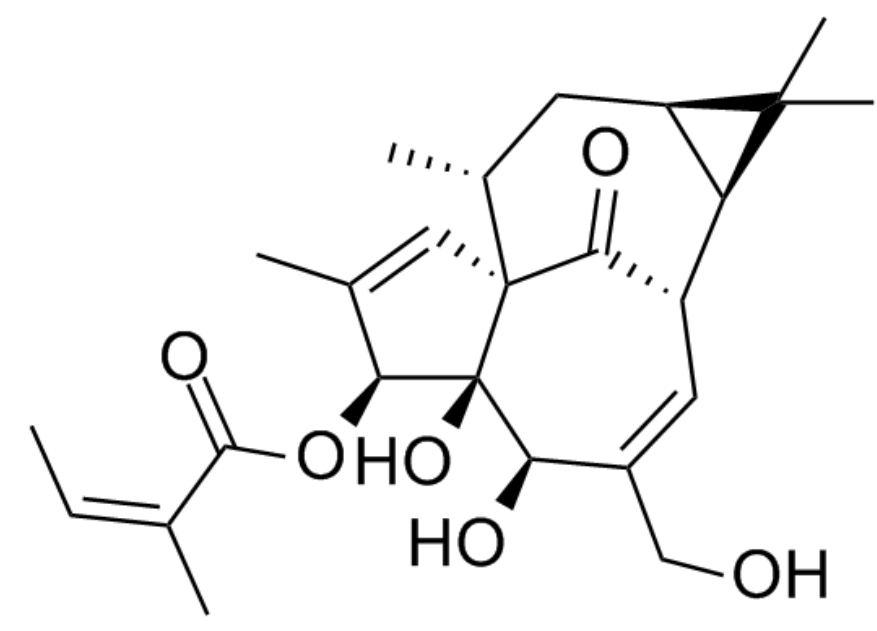

Ingenol mebutate

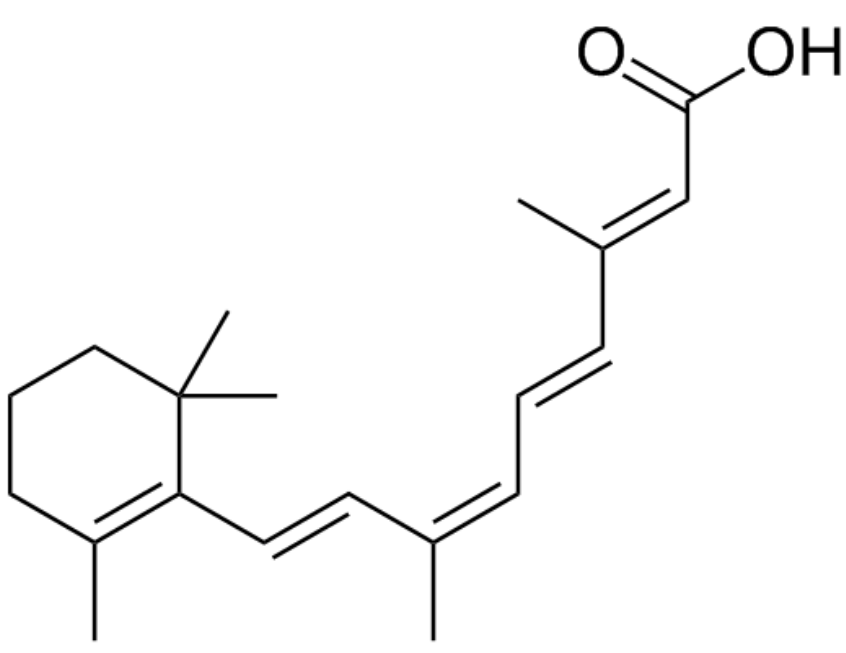

Alitretinoin

Figure 4. Drugs currently used for topical treatment of skin cancer and AK. 


\section{LIST OF TABLES}

Table 1: Physicochemical properties of drugs used for the topical treatment of skin cancer and AK

Table 2: Topical preparations for the treatment of skin cancer and actinic keratosis 
Table 1: Physicochemical properties of drugs used for the topical treatment of skin cancer and AK

\begin{tabular}{|l|l|l|l|l|l|}
\hline Drug & $\mathbf{M W}^{a, c}$ & $\mathbf{L o g} \mathbf{P}^{b}$ & Melting point & $\mathbf{p K}_{\mathbf{a}}{ }^{a, c, d, e, f}$ \\
\hline Alitretinoin & 300.4 & 4.7 & $190-191^{\circ} \mathrm{C}$ & $\begin{array}{l}\text { Very slightly soluble in } \\
\text { aqueous solution }\end{array}$ & 5.1 \\
\hline Diclofenac sodium & 318.1 & - & $283-285^{\circ} \mathrm{C}$ & Sparingly soluble in water & 4.2 \\
\hline Fluorouracil & 130.1 & -0.8 & $282^{\circ} \mathrm{C}$ & Sparingly soluble in water & $8.0,13.0$ \\
\hline Imiquimod & 240.3 & 2.3 & $292-294^{\circ} \mathrm{C}$ & $\begin{array}{l}\text { Practically insoluble in } \\
\text { water }\end{array}$ & 7.3 \\
\hline Ingenol mebutate & 430.5 & 2.0 & $154.1-156.8^{\circ} \mathrm{C}$ & $\begin{array}{l}\text { Practically insoluble in } \\
\text { water }\end{array}$ & 12.7 \\
\hline
\end{tabular}

${ }^{a}$ Moffat et al. (2004)

${ }^{\mathrm{b}}$ Calculated from Molecular Modelling Pro.

${ }^{c}$ Merck Index (2012)

${ }^{\mathrm{d}}$ Product Monograph, Leo Laboratories

${ }^{\text {e}}$ Chollet et al., 1999

${ }^{\mathrm{f}}$ Product monograph, GSK 
Table 2: Topical preparations for the treatment of skin cancer and actinic keratosis

\begin{tabular}{|c|c|c|}
\hline Drug & Formulation & $\begin{array}{l}\text { Indications and treatment } \\
\text { regime }\end{array}$ \\
\hline Alitretinoin & $\begin{array}{l}\text { Panretin } \AA \\
0.1 \% \text { alitretinoin, dehydrated alcohol, } \\
\text { polyethylene glycol } 400, \text { hydroxypropyl } \\
\text { cellulose, butylated hydroxytoluene }\end{array}$ & $\begin{array}{l}\text { AIDS related Kaposi's } \\
\text { sarcoma lesions, not } \\
\text { indicated with systemic } \\
\text { therapy of } K S \text {. } \\
\text { Initially applied twice daily; } \\
\text { may be increased up to four } \\
\text { times daily. Duration of } \\
\text { treatment dependent on } \\
\text { lesion response. }\end{array}$ \\
\hline $\begin{array}{l}\text { Diclofenac } \\
\text { sodium }\end{array}$ & $\begin{array}{l}\text { Solaraze }{ }^{\circledR} \\
3 \% \text { diclofenac sodium, sodium } \\
\text { hyaluronate, benzyl alcohol, macrogol } \\
\text { monomethyl ether } 350 \text {, purified water }\end{array}$ & $\begin{array}{l}\text { Actinic keratosis. } \\
\text { Applied twice daily for up } \\
\text { to } 90 \text { days. }\end{array}$ \\
\hline $\begin{array}{l}\text { Fluorouracil } \\
(5-\mathrm{FU})\end{array}$ & $\begin{array}{l}\text { Carac }{ }^{\circledR} \text { cream } \\
0.5 \% \text { fluorouracil, Microsponge® } \\
\text { [methyl methacrylate / glycol } \\
\text { dimethacrylate cross polymer and } \\
\text { dimethicone], Carbomer } 940, \\
\text { dimethicone, glycerin, methyl gluceth-20, } \\
\text { methyl methacrylate / glycol } \\
\text { dimethacrylate crosspolymer, } \\
\text { methylparaben, octyl hydroxy stearate, } \\
\text { polyethylene glycol 400, polysorbate } 80 \text {, } \\
\text { propylene glycol, propylparaben, purified } \\
\text { water, sorbitan monooleate, stearic acid, } \\
\text { trolamine } \\
\text { Efudex® cream } \\
5 \% \text { fluorouracil, stearyl alcohol, white } \\
\text { soft paraffin, polysorbate } 60, \text { propylene } \\
\text { glycol, methyl parahydroxybenzoate, } \\
\text { propyl parahydroxybenzoate, purified } \\
\text { water } \\
\text { Efudex® solution } \\
2 \% \text { or } 5 \% \text { fluorouracil, propylene glycol, } \\
\text { tris (hydroxymethyl) aminomethane, } \\
\text { hydroxypropyl cellulose, methyl } \\
\text { parahydroxybenzoate, propyl } \\
\text { parahydroxybenzoate, disodium edetate } \\
\text { Fluoroplex@ } \\
1 \% \text { fluorouracil, benzyl alcohol, } \\
\text { emulsifying wax, isopropyl myristate, } \\
\text { mineral oil, purified water, sodium } \\
\text { hydroxide }\end{array}$ & $\begin{array}{l}\text { Actinic keratosis. } \\
\text { Bowen's disease; } \\
\text { superficial basal-cell } \\
\text { carcinoma, } \\
\text { keratoacanthoma. } \\
\text { Applied once or twice daily } \\
\text { for } 4 \text { weeks or longer. }\end{array}$ \\
\hline
\end{tabular}




\begin{tabular}{|c|c|c|}
\hline & & $\begin{array}{l}\text { treatment if lesions not on } \\
\text { head or neck. }\end{array}$ \\
\hline $\begin{array}{l}\text { Fluorouracil, } \\
\text { salicylic acid }\end{array}$ & $\begin{array}{l}\text { Actikerall® } \\
0.5 \% \text { fluorouracil and } 10 \% \text { salicylic acid, } \\
\text { dimethyl sulfoxide, ethanol, ethyl acetate, } \\
\text { pyroxyline, poly(butyl methacrylate, } \\
\text { methyl methacrylate) }\end{array}$ & $\begin{array}{l}\text { Actinic keratosis. Palpable } \\
\text { and/or thick, hypertrophic } \\
\text { lesions. } \\
\text { Applied daily for up to } 12 \\
\text { weeks. Applied less } \\
\text { frequently to areas of skin } \\
\text { with thin epidermis or if } \\
\text { severe side effects occur. }\end{array}$ \\
\hline \multirow[t]{2}{*}{ Imiquimod } & $\begin{array}{l}\text { Aldara }{ }^{\circledR} \\
5 \% \text { imiquimod, isostearic acid, benzyl } \\
\text { alcohol, cetyl alcohol, stearyl alcohol, } \\
\text { white soft paraffin, polysorbate } 60 \text {, } \\
\text { sorbitan stearate, glycerol, methyl } \\
\text { hydroxybenzoate, propyl } \\
\text { hydroxybenzoate, xanthan gum, purified } \\
\text { water }\end{array}$ & $\begin{array}{l}\text { Actinic keratosis. } \\
\text { Applied twice weekly, } \\
\text { application site washed } \\
\text { after } 8 \text { hours; treatment for } \\
\text { up to } 16 \text { weeks. } \\
\text { Superficial basal cell } \\
\text { carcinoma. } \\
\text { Applied five times per week } \\
\text { for up to } 6 \text { weeks, } \\
\text { application site washed } \\
\text { after } 8 \text { hours. Applied to } \\
\text { tumour and to } 1 \text { cm area } \\
\text { surrounding tumour. }\end{array}$ \\
\hline & $\begin{array}{l}\text { Zyclara }{ }^{\circledR} \text { cream } \\
2.5 \% \text { or } 3.75 \% \text { imiquimod, isostearic } \\
\text { acid, benzyl alcohol, cetyl alcohol, } \\
\text { stearyl alcohol, white soft paraffin, } \\
\text { polysorbate } 60 \text {, sorbitan stearate, } \\
\text { glycerol, methyl hydroxybenzoate, propyl } \\
\text { hydroxybenzoate, xanthan gum, purified } \\
\text { water }\end{array}$ & $\begin{array}{l}\text { Actinic keratosis. Non- } \\
\text { hypertrophic, non- } \\
\text { hyperkeratotic, visible or } \\
\text { palpable lesions of head } \\
\text { and face. } \\
\text { Applied once daily for two } \\
\text { treatment cycles each of } 2 \\
\text { weeks separated by } 2 \text { week } \\
\text { washout. Application site } \\
\text { washed after } 8 \text { hours. }\end{array}$ \\
\hline $\begin{array}{l}\text { Ingenol } \\
\text { mebutate }\end{array}$ & $\begin{array}{l}\text { Picato }{ }^{\circledR} \\
150 \mu \mathrm{g} / \mathrm{g} \text { or } 500 \mu \mathrm{g} / \mathrm{g} \text { of ingenol } \\
\text { mebutate, isopropyl alcohol, } \\
\text { hydroxyethylcellulose, citric acid } \\
\text { monohydrate, sodium citrate, benzyl } \\
\text { alcohol, purified water }\end{array}$ & $\begin{array}{l}\text { Actinic keratosis. Non- } \\
\text { hyperkeratotic, non- } \\
\text { hypertrophic lesions. } \\
\text { Apply one tube daily for } \\
\text { three days if lesions on face } \\
\text { and scalp; apply one tube } \\
\text { daily for two days if lesions } \\
\text { on trunk and extremities. } \\
\text { No washing or touching } \\
\text { application site for } 6 \text { hours } \\
\text { after application }\end{array}$ \\
\hline
\end{tabular}

